\title{
Synthesis and Evaluation of Tricyclic Derivatives Containing a Non-Aromatic Amide as Poly(ADP-ribose)polymerase-1 (PARP-1) Inhibitors
}

\author{
Chun-Ho Park, ${ }^{\dagger, \#}$ Kwangwoo Chun, ${ }^{\dagger}$ Jong-Hee Choi, ${ }^{\dagger}$ Wan-Keun Ji, ${ }^{\dagger}$ Hyun Young Kim, ${ }^{\ddagger}$ \\ Seung Hyun Kim, ${ }^{\ddagger}$ Gyoonhee Han, ${ }^{\S}$ and Myung-Hwa Kim ${ }^{\dagger, *}$ \\ †Drug Discovery Laboratory, R\&D Center, Jeil Pharmaceutical Co., Kyunggi-Do 449-861, Korea \\ EE-mail:mhkim@jeilpharm.co.kr \\ ¿Department of Neurology, Hanyang University College of Medicine, Seoul 133-791, Korea \\ ${ }^{\S}$ Department of Biotechnology, Yonsei University, Seoul 120-740, Korea \\ ${ }^{\#}$ Graduate Program in Biomaterials Science and Engineering, Yonsei University, Seoul 120-740, Korea \\ Received February 24, 2011, Accepted March 31, 2011
}

\begin{abstract}
A series of potent tricyclic derivatives with a non-aromatic amide as potent PARP-1 inhibitors were successfully synthesized and their PARP-1 inhibitory activity was evaluated. Among the derivatives, 2-(1propylpiperidin-4-yloxy)-7,8,9,10-tetrahydrophenanthridin-6(5H)-one 23c displayed potent activity in a PARP-1 enzymatic assay and cell-based assay $\left(\mathrm{IC}_{50}=0.142 \mu \mathrm{M}, \mathrm{ED}_{50}=0.90 \mu \mathrm{M}\right)$ with good water solubility. Further, molecular modeling studies confirmed the obtained biological results.
\end{abstract}

Key Words : Poly(ADP-ribose)polymerase, PARP-1 inhibitor, Phenanthridines

\section{Introduction}

Poly(ADP-ribose) polymerase-1 (PARP-1, EC 2.4.2.30) is an abundant chromatin-bound nuclear enzyme in eukaryotes as a key DNA damage sensor that facilitates the repair of DNA. ${ }^{1,2}$ The role of PARP-1 is important in a number of cellular process related to ischemia-reperfusion injury and cancer. When triggered by DNA damage, PARP-1 catalyzes the transfer of ADP-ribose units from intracellular nicotinamide adenine dinucleotide $\left(\mathrm{NAD}^{+}\right)$to synthesize a polymer of ADP-ribose on either the PARP protein itself or various other protein acceptors. Subsequently, DNA repair, recombination, cell proliferation, or cell death occurs based upon genomic stability. ${ }^{2}$ Furthermore, PARP-1 has also been implicated in a caspase-independent apoptosis pathway mediated by apoptosis-inducing factor. ${ }^{3}$ PARP-1 inhibitors provided remarkable protection from tissue damage in various forms of reperfusion injury, inflammation, and neurodegenerative disorders in animal models. ${ }^{4}$ Indeed, inhibition of PARP-1 by pharmacological agents could be useful in the treatment of stroke, traumatic brain injury, Parkinson's disease, cancer, and several other diseases involved in PARP-1 activation. $^{5-7}$

Over the last two decades, a large number of PARP-1 inhibitors such as AZD2281 (2), AG14361 (3), and PJ34 (4) have been developed, many of which are currently in clinical trials. ${ }^{6-8-15}$ Most PARP-1 inhibitors are competitive with $\mathrm{NAD}^{+}$and these structures are typically nicotinamide or benzamide analogs (Fig. 1). The aromatic amide group of these compounds has been shown to form hydrogen bonds with the Gly-863 and Ser-904 amino acid residues of the PARP enzyme and also binds effectively to the aryl residues, Tyr907 and Tyr896, through a sandwiched hydrophobic $\pi-\pi$ interaction. ${ }^{8,10,13}$
We have recently disclosed tricyclic PARP-1 inhibitors, substituted thiopyrano[3,4-c]quinoline-9-carboxamide derivatives. ${ }^{16}$ These compounds include a non-aromatic Aring and fit well to the active site even though their conformations are not flat. In additon, these derivatives displayed good enzyme inhibitory activity and a few compounds<smiles>NC(=O)c1cccnc1</smiles>

Nicotinamide (1)<smiles>CN(C)Cc1ccc(-c2nc3cccc4c3n2CCNC4=O)cc1</smiles>

AZD2281 (2)

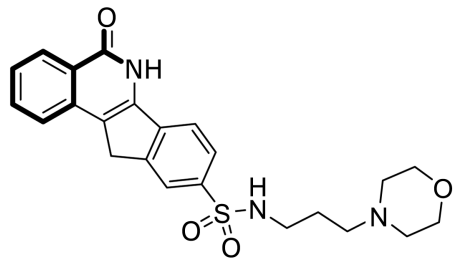

Inotek indeno[1,2-c]isoquinolinone (5)<smiles>O=C(c1cc(Cc2n[nH]c(=O)c3ccccc23)ccc1F)N1CCN(C(=O)C2CC2)CC1</smiles>

AZD2281 (2)<smiles>CN(C)CC(=O)Nc1ccc2[nH]c(=O)c3ccccc3c2c1</smiles><smiles>CN(C)CCNC(=O)c1ccc2[nH]c(=O)c3c(c2c1)CCSC3</smiles>

(6)
Figure 1. Published PARP-1 inhibitors and thiopyrano[3,4-c]quinoline (6) 
displayed significant cellular activity. A fair number of compounds such as inhibitor $\mathbf{6}$, however, suffered from poor cellular potency. In effort to further optimize thiopyrano[3,4c] quinoline-9-carboxamides in order to improve the the potency on the cellular level, substituted 6-oxo-5,6,7,8,9,10hexahydrophenanthridin-2-carboxamides and 7,8,9,10-tetrahydrophenanthridin-6(5H)-ones were designed and synthesized. Crystallographic structure of the human PARP-1 catalytic domain (PDB code: 1UK0) was obtained from the Protein Data Bank (PDB) database,${ }^{10}$ and docking studies of these compounds were performed to approach the development of more potent inhibitors. Additionally, their PARP-1 inhibitory activities were evaluated.

\section{Results and Discussion}

Chemistry. The synthetic routes for the newly synthesized substituted 6-oxo-5,6,7,8,9,10-hexahydrophenanthridin-2-carboxamide derivatives are outlined in Schemes 1 and 2. Cyclohexanone 7 reacted with morpholine $\mathbf{8}$ in the presence of catalytic $p$-toluenesulfonic acid monohydrate and subsequently treated without further purification. ${ }^{17,18}$ The ketamide 11, prepared by reaction of the enamine 9 with ethyl 4-isocyanobenzoate 10, was cyclized in $70 \%$ sulfuric acid to give the ethyl 6-oxo-5,6,7,8,9,10-hexahydrophenanthridin-2-carboxylate 12. ${ }^{19}$ Hydrolysis of the carboxylate 12 with $1 N \mathrm{NaOH}$ solution gave its corresponding carboxylic acid 13, which was optimized by conversion of acid group to amide. 6-oxo-5,6,7,8,9,10-hexahydrophenanthridin-2-carboxamides 15a-g were synthesized by amide coupling with aliphatic amine or Boc-protected diamine using 1-ethyl-3-(3-dimethylaminopropyl) carbodiimide hydrochloride (EDCI). The analogues 23a-c were prepared from 9 as depicted in Scheme 2.

2-Methoxy-7,8,9,10-tetrahydrophenanthridin-6(5H)-one 18 was obtained from the enamine 9 according to the method described for the preparation of the carboxylate $\mathbf{1 2}$. Demethylation of compound $\mathbf{1 8}$ with boron tribromide in dichloromethane gave alcohol 19, which was alkylated with the bromide 20 in the presence of base to afford the Bocprotected amine 21. After deprotection of $\mathbf{2 1}$ under acidic condition, alkyl amine $\mathbf{2 3}$ was synthesized by reductive<smiles>CCCOC(=O)c1ccc([N+](=O)[O-])cc1</smiles><smiles>CCOC(=O)c1ccc2[nH]c(=O)c3c(c2c1)CCCC3</smiles>

12<smiles>O=C(O)c1ccc2[nH]c(=O)c3c(c2c1)CCCC3</smiles>

13<smiles>[R]NCCC</smiles>

14

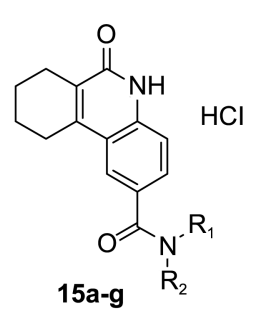

Scheme 1. Reagents and conditions: (a) $p$ - $\mathrm{TsOH} \cdot \mathrm{H}_{2} \mathrm{O}$, toluene, reflux, $12 \mathrm{hr}$ (b) i) toluene, rt, 1 day ii) $2 \mathrm{~N} \mathrm{HCl}$, rt, overnight (c) $70 \% \mathrm{H}_{2} \mathrm{SO}_{4}$, rt, $14 \mathrm{hr}$ (d) $1 \mathrm{~N} \mathrm{NaOH}, \mathrm{MeOH}, 50^{\circ} \mathrm{C}, 12 \mathrm{hr}$ (e) i) EDC, HOBt, DMF, rt, 10-15 hr ii) $3.7 \mathrm{M} \mathrm{HCl}$ in 1,4-dioxane, rt, 1-10 hr.<smiles>C1CCC(N2CCOCC2)CC1</smiles>

9<smiles>COc1ccc(NC(=O)C2CCCCC2=O)cc1</smiles><smiles>CC1CCc2c(c3cc(O)ccc3[nH]c2=O)C1</smiles><smiles>CC(C)(C)OC(=O)N1CCC(Br)CC1</smiles>

20<smiles>CC(C)(C)OC(=O)N1CCC(Oc2ccc3[nH]c(=O)c4c(c3c2)CCCC4)CC1</smiles>

21<smiles>O=c1[nH]c2ccc(OC3CCNCC3)cc2c2c1CCCC2</smiles>

22<smiles>[R3]N1CCC(Oc2ccc3[nH]c(=O)c4c(c3c2)CCCC4)CC1</smiles>

Scheme 2. Reagents and conditions: (a) i) toluene, rt, 1 day ii) $2 \mathrm{~N} \mathrm{HCl}$, rt, overnight; (b) $70 \% \mathrm{H}_{2} \mathrm{SO}_{4}, \mathrm{rt}, 14 \mathrm{hr}$; (c) $\mathrm{BBr}_{3}, \mathrm{CH}_{2} \mathrm{Cl}_{2}, \mathrm{rt}, 2 \mathrm{hr}$; (d) $\mathrm{KOH}, i-\mathrm{PrOH}$, reflux, 2 day; (e) $3.7 \mathrm{M} \mathrm{HCl}$, 1,4-dioxane, rt, 12 hr; (f) aldehyde, $\mathrm{NaB}(\mathrm{OAc})_{3} \mathrm{H}, \mathrm{AcOH}, \mathrm{MeOH} /$ dichloromethane, rt, 3-5 hr; (g) $3.7 \mathrm{M} \mathrm{HCl}, 1$,4-dioxane, rt, 10-12 hr. 
amination using an appropriate aldehyde. Finally, the $\mathrm{HCl}$ salt of $N$-substituted amine 23 was prepared by $3.7 N \mathrm{HCl}$ in 1,4-dioxane to enhance water solubility. The structure of the synthesized phenanthridine analogues was established on the basis of ${ }^{1} \mathrm{H}$ NMR and mass spectral analysis.

Biology. The PARP-1 inhibitory activity of synthesized phenanthridine derivatives $\mathbf{1 5 a - g}$ was evaluated in vitro PARP-1 enzymatic assay and cell-based assay, which is summarized in Table 1 and 2. An $\mathrm{IC}_{50}$ and $\mathrm{ED}_{50}$ value of the indeno[1,2-c]isoquinolinone (5) is included in Table 1 as a reference. A series of indeno[1,2-c]isoquinolinone (5) recently described by the Inoteck group showed very potent PARP-1 inhibitory activity. ${ }^{12}$ Generally, synthesized phenanthridine compounds showed a profile of reasonable enzymatic potencies. Some compounds (15a, 15c and 15d), however, displayed poor cellular activity. The polar group at the end of the derivative (15c and 15d) chain seems to prevent cell permeability. The piperidin derivative $\mathbf{1 5 b}$ showed

Table 1. Enzyme and cellular activity of the synthesized compounds 15a-g

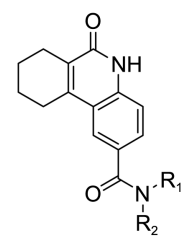

\begin{tabular}{|c|c|c|c|}
\hline Compds & $\mathrm{NR}_{1} \mathrm{R}_{2}$ & $\mathrm{IC}_{50}(\mu \mathrm{M})^{a}$ & $\mathrm{ED}_{50}(\mu \mathrm{M})^{b}$ \\
\hline $\mathbf{5}^{c}$ & & 0.057 & 1.01 \\
\hline $15 a$ & & 0.085 & 25.31 \\
\hline $15 b$ & & 0.050 & 7.63 \\
\hline $15 c$ & & 0.076 & $>30$ \\
\hline 15d & & 0.071 & 26.73 \\
\hline $15 e$ & & 0.065 & 2.11 \\
\hline $15 f$ & & 0.098 & $>30$ \\
\hline $15 \mathrm{~g}$ & & 0.288 & 2.36 \\
\hline
\end{tabular}

${ }^{a}$ Enzymatic assays followed a commercially available protocol (Trevigen kit, 4671-096-K) in 384 well plates. Values are the mean of triplicate experiments. ${ }^{b}$ The CHO-K1 (Chinese hamster ovary) cell line was used for cell based assay. Values are the mean of quadruplicate experiments. ${ }^{c}$ Indeno[1,2-c] isoquinolinone (5, Ref 12). The data was taken from our assay protocol. moderate PARP-1 cellular activity. The $N$-alkyl piperazine derivative 15e and $N$-cycloalkyl piperazine derivatives $\mathbf{1 5 g}$ displayed significant activities in enzyme assays and slightly potent activities in cellular assays. As mentioned above, the compound $\mathbf{1 5 f}$ with the polar group at the end of the chain decreased cellular activity significantly.

The activities of substituted 7,8,9,10-tetrahydrophenanthridin-6(5H)-one derivatives 23a-c are given in Table 2. When piperidine analogs were fused to the C-2 hydroxy position, hydrophobic interactions with the adenine-ribose binding site (AD site) and water solubility were increased significantly. The $\mathrm{N}$-methyl, ethyl, and propyl piperidine derivatives (23a-23c) demonstrated a dramatic increase in cellular potency relative to parent $\mathbf{2 2}$, while maintaining good enzyme potency. Moreover, 23a and 23c showed good

Table 2. Enzyme and cellular activity of the synthesized compounds 22 and 23a-c

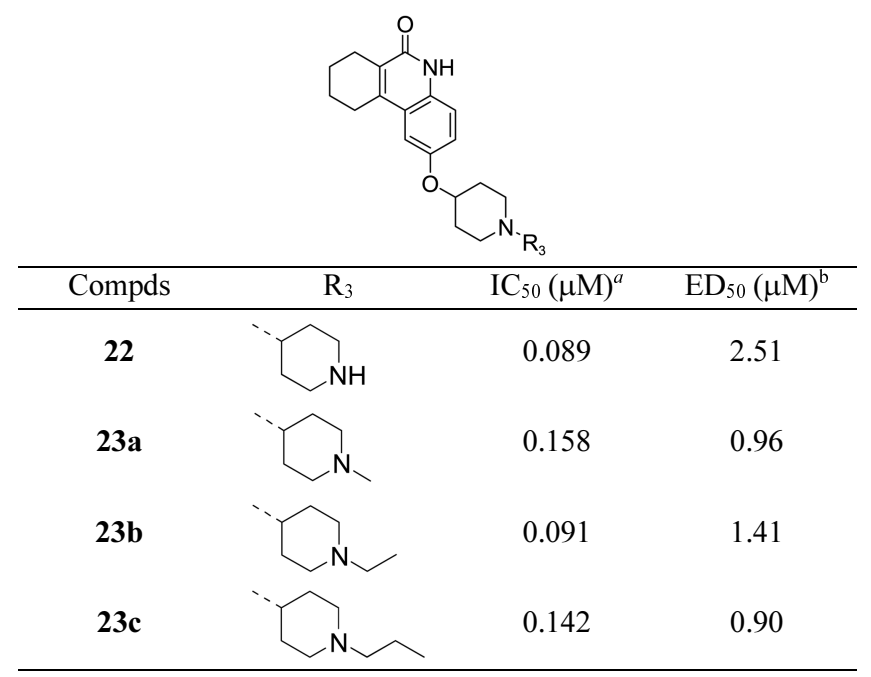

$\overline{{ }^{a} \text { Enzymatic assays followed a commercially available protocol (Trevigen }}$ kit, 4671-096-K) in 384 well plates. Values are the mean of triplicate experiments. ${ }^{b}$ The CHO-K1 (Chinese hamster ovary) cell line was used for cell based assay. Values are the mean of quadruplicate experiments.

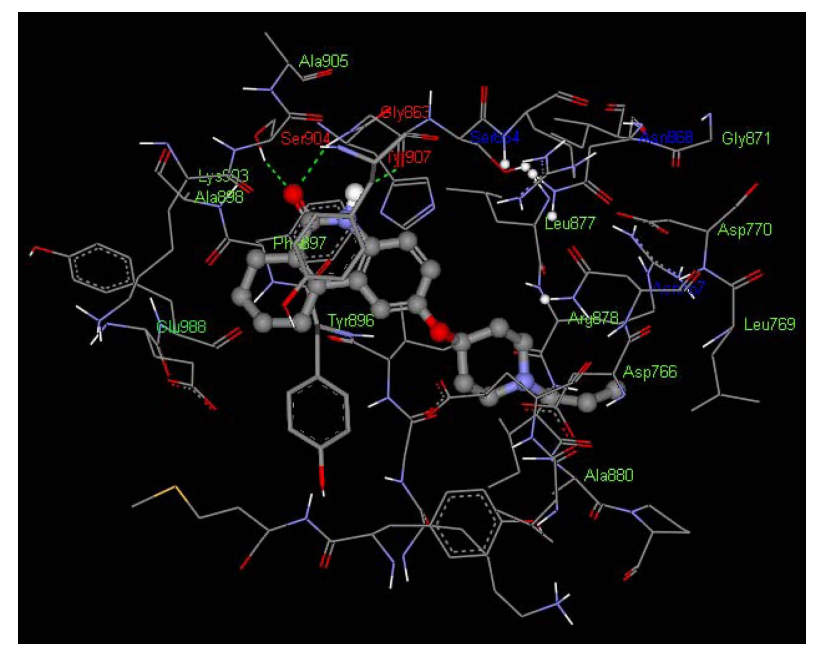

Figure 2. Docking of compound 23c in the catalytic domain of human PARP-1 (PDB code: 1UK0). (Kinoshita, Nakanishi, Warizaya, Iwashita, Kido, Hattori and Fujii 2004). 
potencies similar to $\mathbf{5}$ in the cell-based assay. In an attempt to comprehend the binding conformation of piperidine analogs fused to the C-2 hydroxy position in the active site of the enzyme, propyl piperidine derivative 23c was selected for due to its overall profile. An X-ray co-crystal structure of PARP-1 with 23c is shown in Figure 2. The carboxamido group of the compound (23c) formed key hydrogen bond interactions to Ser904 and Gly863 of the enzyme. The amine of the piperidine group was posted near backbone of Ala880 and side chain of Asp766 for polar interaction. Furthermore, the propyl group of the compound $(\mathbf{2 3 c})$ formed hydrophobic interaction with hydrophibic pocket (Asp766, Leu769, Arg878, Ile879, and Ala880).

\section{Conclusion}

In conclusion, we have described a straightforward synthesis, docking study and biological evaluation of tricyclic derivatives with a non-aromatic amide as potent PARP-1 inhibitors. Compound 23c was found to be highly potent in enzyme and cell-based assays $\left(\mathrm{IC}_{50}=0.142 \mu \mathrm{M}, \mathrm{ED}_{50}=\right.$ $0.90 \mu \mathrm{M}$ ) with good water solubility. These findings suggest that a potent PARP-1 inhibitor 23c could be a useful therapeutic candidate for cancers and ischemic stroke. Further evaluation of these derivatives such as pharmacokinetic (PKs), CNS penetration is ongoing and will be reported in the near future.

\section{Experimental Section}

General. Melting points were determined on a Stuart SMP3 melting point apparatus and are uncorrected. ${ }^{1} \mathrm{H}$ NMR spectra were recorded at $400 \mathrm{MHz}$ on a Varian 400 Mercury plus spectrometer; chemical shifts are reported in $\delta$ (ppm) units relative to the internal reference tetramethylsilane (TMS). Mass spectra were performed on an Applied Biosystems API 2000 mass spectrometer and Agilent 1200 series LC system. All compounds were routinely checked by TLC and ${ }^{1} \mathrm{H}$ NMR. TLC was performed on glass-backed silica gel plates (Merck, DC Kieselgel $60 \mathrm{~F}_{254}$ ). Flash chromatography was carried out on E. Merck Kieselgel 60 silica gel (230-400 mesh). All chemicals were obtained commercially. All solvents were reagent-grade and were used without further purification, unless otherwise stated.

Ethyl 4-(2-oxocyclohexanecarboxamido)benzoate (11). To a stirred solution of 4-cyclohexanone 7 (3.0 g, 30.56 $\mathrm{mmol})$ in toluene $(60 \mathrm{~mL})$ were added morpholine 8 (3.2 $\mathrm{mL}, 36.67 \mathrm{mmol})$ and catalytic $p$-TsOH $\cdot \mathrm{H}_{2} \mathrm{O}(290 \mathrm{mg}, 1.53$ mmol). The resulting mixture was refluxed for $12 \mathrm{hr}$ with a Dean-Stark trap. After completion, the mixture was cooled to room temperature and evaporated under reduced pressure. The residue was concentrated in vacuo to afford the unstable enamine 9, which was used without further purification.

Ethyl 4-isocyanatobenzoate 10 (8.9 g, $46.55 \mathrm{mmol})$ in toluene $(20 \mathrm{~mL})$ was added dropwise to a stirred solution of unstable enamine 9 in toluene $(60 \mathrm{~mL})$ at room temperature, and the stirring was continued at room temperature for 1day.
Then $2 N \mathrm{HCl}(12.0 \mathrm{~mL}, 24.00 \mathrm{mmol})$ was added, and the resulting mixture was stirred at room temperature overnight. The mixture was cautiously neutralized with $2 \mathrm{~N} \mathrm{NaOH}$, and the precipitate was filtered. The filtrate was taken up with water and extracted with dichloromethane. The organic layer was washed with brine, dried over $\mathrm{Na}_{2} \mathrm{SO}_{4}$, filtered and concentrated. The residue was then purified by flash column chromatography (hexane:ethyl acetate $=1: 5$ ) to afford the title compound 11 as a yellow solid (2.5 g, 21\%, 2 step).

${ }^{1} \mathrm{H}$ NMR (400 MHz, DMSO-d $)$ ): $\delta 9.69$ (s, 1H), 8.02 (d, $J$ $=8.4 \mathrm{~Hz}, 2 \mathrm{H}), 7.64(\mathrm{~d}, J=8.6 \mathrm{~Hz}, 2 \mathrm{H}), 7.59(\mathrm{~d}, J=8.6 \mathrm{~Hz}$, $2 \mathrm{H}), 4.35$ (q, $J=7.2 \mathrm{~Hz}, 2 \mathrm{H}), 2.33-2.29(\mathrm{~m}, 4 \mathrm{H}), 1.80-1.74$ $(\mathrm{m}, 4 \mathrm{H}), 1.60(\mathrm{~s}, 1 \mathrm{H}), 1.38(\mathrm{t}, J=6.8 \mathrm{~Hz}, 3 \mathrm{H})$.

Ethyl 6-oxo-5,6,7,8,9,10-hexahydrophenanthridin-2carboxylate (12). Ketamide 11 (2.0 g, $6.91 \mathrm{mmol})$ was suspended in $70 \mathrm{~mL}$ of $70 \% \mathrm{H}_{2} \mathrm{SO}_{4}$ and the resulting mixture was stirred at room temperature for $14 \mathrm{hr}$. The reaction mixture was poured into ice water and stirred for $0.5 \mathrm{hr}$. The precipitate was filtered, washed with water, and dried in vacuo to afford the title compound $\mathbf{1 2}$ as a brown solid (1.0 g, 53\%).

${ }^{1} \mathrm{H}$ NMR (400 MHz, DMSO- $\left.d_{6}\right): \delta 13.11(\mathrm{br}, 1 \mathrm{H}), 8.47$ (s, $1 \mathrm{H}), 8.13(\mathrm{~d}, J=8.8 \mathrm{~Hz}, 1 \mathrm{H}), 7.57(\mathrm{~d}, J=8.8 \mathrm{~Hz}, 1 \mathrm{H}), 4.38$ $(\mathrm{q}, J=7.2 \mathrm{~Hz}, 2 \mathrm{H}), 3.02(\mathrm{~s}, 2 \mathrm{H}), 2.66(\mathrm{~d}, J=6.0 \mathrm{~Hz}, 2 \mathrm{H})$, $1.90(\mathrm{~d}, J=6.0 \mathrm{~Hz}, 2 \mathrm{H}), 1.83(\mathrm{~d}, J=6.0 \mathrm{~Hz}, 2 \mathrm{H}), 1.38$ (t, $J$ $=6.8 \mathrm{~Hz}, 3 \mathrm{H})$.

6-Oxo-5,6,7,8,9,10-hexahydrophenanthridin-2-carboxylic acid (13). To a stirred solution of carboxylate 12 (1.0 g, $3.68 \mathrm{mmol})$ in $\mathrm{MeOH}(12 \mathrm{~mL})$ was added aqueous $1 N$ $\mathrm{NaOH}$ solution $(18.4 \mathrm{~mL})$. The mixture was then heated to $50{ }^{\circ} \mathrm{C}$ and stirred for $12 \mathrm{hr}$. After completion, the cooled mixture was poured on water and acidified to $\mathrm{pH} 3$ with $2 \mathrm{~N}$ $\mathrm{HCl}$. The resulting precipitate was filtered and washed with water, yielding the title compound $\mathbf{1 3}$ as a white solid (710 $\mathrm{mg}, 79 \%)$.

${ }^{1} \mathrm{H}$ NMR (400 MHz, DMSO- $d_{6}$ ): $\delta 12.86(\mathrm{br}, 1 \mathrm{H}), 11.92$ (s, 1H), 8.23 (s, 1H), $7.96(\mathrm{~d}, J=8.4 \mathrm{~Hz}, 1 \mathrm{H}), 7.32(\mathrm{~d}, J=$ $8.8 \mathrm{~Hz}, 1 \mathrm{H}), 2.84$ (s, 2H), 1.78 (d, $J=4.4 \mathrm{~Hz}, 2 \mathrm{H}), 1.70$ (d, $J$ $=4.8 \mathrm{~Hz}, 2 \mathrm{H})$.

General Procedure for the Synthesis of 6-Oxo-5,6,7,8, 9,10-hexahydrophenanthridin-2-carboxamide Derivatives (15a-g). To a stirred solution of 6-oxo-5,6,7,8,9,10-hexahydrophenanthridin-2-carboxylic acid 13 (40 mg, 0.16 mmol) in DMF (3 mL) were added $N$-(3-dimethylaminopropyl)- $N$ '-ethylcarbodiimide hydrochloride (EDCI, $35 \mathrm{mg}$, $0.18 \mathrm{mmol}$ ), hydroxybenzotriazole (HOBt, $25 \mathrm{mg}, 0.18$ $\mathrm{mmol})$, and an appropriate amine compound ( $0.18 \mathrm{mmol})$. The resulting mixture was stirred at room temperature for $10-15 \mathrm{hr}$ and poured into saturated aqueous $\mathrm{NaHCO}_{3}$ solution. The mixture was extracted with ethyl acetate, washed with brine, dried over $\mathrm{Na}_{2} \mathrm{SO}_{4}$, and concentrated to dryness. The residue was then purified by flash column chromatography (hexane:ethyl acetate $=1: 1$ or chloroform: methanol $=1: 10$ ) to afford 6-oxo-5,6,7,8,9,10-hexahydrophenanthridin-2-carboxamide as a free base.

$3.7 \mathrm{M} \mathrm{HCl}$ in 1,4-dioxane (30 equiv.) was added to a stirred solution of 6-oxo-5,6,7,8,9,10-hexahydrophenanthri- 
din-2-carboxamide in 1,4-dioxane $(3-5 \mathrm{~mL})$ at $0{ }^{\circ} \mathrm{C}$. After stirring for $1-10 \mathrm{hr}$ at room temperature, the reaction mixture was concentrated in vacuo to give the title compound $\mathbf{1 5}$.

The physical and analytical data of the synthesized title compounds are given, as follows:

$\mathrm{N}$-[2-(Dimethylamino)ethyl]-6-oxo-5,6,7,8,9,10-hexahydrophenanthridin-2-carboxamide (15a). White solid; 70\%; ${ }^{1} \mathrm{H}$ NMR (400 MHz, DMSO- $\left.d_{6}\right): \delta 11.88(\mathrm{~s}, 1 \mathrm{H}), 10.63(\mathrm{br}$, $1 \mathrm{H}), 8.95-8.93(\mathrm{~m}, 1 \mathrm{H}), 8.27(\mathrm{~s}, 1 \mathrm{H}), 7.96(\mathrm{~d}, J=8.4 \mathrm{~Hz}$, $1 \mathrm{H}), 7.31(\mathrm{~d}, J=8.8 \mathrm{~Hz}, 1 \mathrm{H}), 3.65-3.64(\mathrm{~m}, 2 \mathrm{H}), 3.27-3.26$ $(\mathrm{m}, 2 \mathrm{H}), 2.90-2.88(\mathrm{~m}, 2 \mathrm{H}), 2.84(\mathrm{~s}, 3 \mathrm{H}), 2.82(\mathrm{br}, 2 \mathrm{H}), 1.81-$ $1.73(\mathrm{~m}, 4 \mathrm{H})$.

6-Oxo- $N$-[2-(piperidin-1-yl)ethyl]-5,6,7,8,9,10-hexahydrophenanthridin-2-carboxamide (15b). White solid; 54\%; ${ }^{1} \mathrm{H}$ NMR (400 MHz, DMSO- $\left.d_{6}\right): \delta 11.88$ (s, 1H), 9.84 (br, 1H), 8.98 (br, 1H), 8.27 (s, 1H), 7.96 (d, $J=8.6 \mathrm{~Hz}, 1 \mathrm{H})$, $7.31(\mathrm{~d}, J=8.4 \mathrm{~Hz}, 1 \mathrm{H}), 3.68-3.67(\mathrm{~m}, 2 \mathrm{H}), 2.56-3.52(\mathrm{~m}$, 2H), 3.24-3.22 (m, 2H), 2.97-2.85 (m, 4H), 2.32 (br, 2H), $1.90-1.72(\mathrm{~m}, 8 \mathrm{H}), 1.43-1.30(\mathrm{~m}, 2 \mathrm{H})$.

$\mathrm{N}$-(2-Aminoethyl)-6-oxo-5,6,7,8,9,10-hexahydrophenanthridin-2-carboxamide (15c). White solid; 56\%; ${ }^{1} \mathrm{H}$ NMR (400 MHz, DMSO- $\left.d_{6}\right)$ : $\delta 11.86(\mathrm{~s}, 1 \mathrm{H}), 8.95$ (br, 1H), 8.28 $(\mathrm{s}, 1 \mathrm{H}), 8.16(\mathrm{~m}, 3 \mathrm{H}), 7.98(\mathrm{~d}, J=8.8 \mathrm{~Hz}, 1 \mathrm{H}), 7.31(\mathrm{~d}, J=$ $8.4 \mathrm{~Hz}, 1 \mathrm{H}), 3.56-3.52(\mathrm{~m}, 2 \mathrm{H}), 3.02-2.98(\mathrm{~m}, 2 \mathrm{H}), 2.90(\mathrm{~m}$, $2 \mathrm{H}), 2.45(\mathrm{~m}, 2 \mathrm{H}), 1.80-1.79(\mathrm{~m}, 2 \mathrm{H}), 1.73-1.71(\mathrm{~m}, 2 \mathrm{H})$.

2-(Piperazine-1-carbonyl)-7,8,9,10-tetrahydrophenanthridin-6(5H)-one (15d). Pale yellow solid; 69\%; ${ }^{1} \mathrm{H}$ NMR (400 MHz, DMSO-d $)$ ): $\delta 11.82(\mathrm{~s}, 1 \mathrm{H}), 9.58(\mathrm{~s}, 1 \mathrm{H}), 7.74(\mathrm{~s}$, $1 \mathrm{H}), 7.51(\mathrm{~d}, J=8.0 \mathrm{~Hz}, 1 \mathrm{H}), 7.32(\mathrm{~d}, J=8.0 \mathrm{~Hz}, 1 \mathrm{H}), 3.71$ (br, 1H), 3.12 (br, 4H), 2.82 (s, 2H), 2.44 (br, 2H), 1.77 (d, J $=5.2 \mathrm{~Hz}, 2 \mathrm{H}), 1.70(\mathrm{~d}, J=5.2 \mathrm{~Hz}, 2 \mathrm{H})$.

2-(4-\{2-[4-(4-Fluorophenyl)-5,6-dihydropyridin-1(2H)yl]ethyl\}piperazine-1-carbonyl)-7,8,9,10-tetrahydrophenanthridin-6(5H)-one (15e). White solid; 41\%; ${ }^{1} \mathrm{H}$ NMR (400 MHz, DMSO- $\left.d_{6}\right): \delta 11.87(\mathrm{~s}, 1 \mathrm{H}), 11.61(\mathrm{br}, 1 \mathrm{H}), 11.10$ (br, $1 \mathrm{H}), 7.77(\mathrm{~s}, 1 \mathrm{H}), 7.57-7.53(\mathrm{~m}, 3 \mathrm{H}), 7.36(\mathrm{~d}, J=8.0 \mathrm{~Hz}$, $1 \mathrm{H}), 7.23(\mathrm{t}, J=8.8 \mathrm{~Hz}, 2 \mathrm{H}), 6.21(\mathrm{~s}, 1 \mathrm{H}), 4.15(\mathrm{~m}, 2 \mathrm{H})$, $3.72-3.24(\mathrm{~m}, 14 \mathrm{H}), 2.84(\mathrm{~m}, 4 \mathrm{H}), 2.46(\mathrm{~m}, 2 \mathrm{H}), 1.79-1.78$ $(\mathrm{m}, 2 \mathrm{H}), 1.72-1.71(\mathrm{~m}, 2 \mathrm{H})$.

2-[4-(Pyridin-4-yl)piperazine-1-carbonyl]-7,8,9,10-tetrahydrophenanthridin-6(5H)-one (15f). Yellow solid; 49\%; ${ }^{1} \mathrm{H}$ NMR (400 MHz, DMSO- $\left.d_{6}\right): \delta 14.06$ (br, 1H), 11.87 (s, $1 \mathrm{H}), 8.29(\mathrm{t}, J=5.6 \mathrm{~Hz}, 2 \mathrm{H}), 7.77(\mathrm{~s}, 1 \mathrm{H}), 7.55(\mathrm{~d}, J=8.4$ $\mathrm{Hz}, 1 \mathrm{H}), 7.37$ (d, $J=8.4 \mathrm{~Hz}, 1 \mathrm{H}), 7.17$ (d, $J=5.6 \mathrm{~Hz}, 2 \mathrm{H})$, 3.78-3.60 (m, 8H), $2.82(\mathrm{~m}, 2 \mathrm{H}), 2.46(\mathrm{~m}, 2 \mathrm{H}), 1.78-1.77$ $(\mathrm{m}, 2 \mathrm{H}), 1.72-1.70(\mathrm{~m}, 2 \mathrm{H})$.

2-(4-Cyclopentylpiperazine-1-carbonyl)-7,8,9,10-tetrahydrophenanthridin-6(5H)-one (15g). White solid; 41\%; ${ }^{1} \mathrm{H}$ NMR (400 MHz, DMSO- $d_{6}$ ): $\delta 11.81(\mathrm{~s}, 1 \mathrm{H}), 11.39$ (br, 1H), $7.74(\mathrm{~s}, 1 \mathrm{H}), 7.52(\mathrm{~d}, J=8.4 \mathrm{~Hz}, 1 \mathrm{H}), 7.32$ (d, $J=8.4$ $\mathrm{Hz}, 1 \mathrm{H}), 3.54-3.36(\mathrm{~m}, 6 \mathrm{H}), 3.10-3.02(\mathrm{~m}, 2 \mathrm{H}), 2.82(\mathrm{~m}$, 2H), $2.45(\mathrm{~m}, 2 \mathrm{H}), 1.97(\mathrm{~m}, 2 \mathrm{H}), 1.78-1.70(\mathrm{~m}, 7 \mathrm{H}), 1.54-$ $1.51(\mathrm{~m}, 4 \mathrm{H})$.

$\mathrm{N}$-(4-Methoxyphenyl)-2-oxocyclohexanecarboxamide (17). 4-Methoxyphenyl isocyanate 16 (9 g, $60.34 \mathrm{mmol})$ in toluene $(30 \mathrm{~mL})$ was added dropwise to a stirred solution of unstable enamine 9 (6.8 g, $40.75 \mathrm{mmol})$ in toluene $(90 \mathrm{~mL})$ at room temperature, and the stirring was continued at room temperature for 1 day. Then $2 N \mathrm{HCl}(12.0 \mathrm{~mL}, 24.00 \mathrm{mmol})$ was added, and the resulting mixture was stirred at room temperature overnight. The mixture was taken up with water and extracted with ethyl acetate. The organic layer was washed with brine, dried over $\mathrm{Na}_{2} \mathrm{SO}_{4}$, filtered and concentrated. The residue was then purified by flash column chromatography (hexane:ethyl acetate $=1: 6$ ) to afford the title compound 17 as a white solid (2.5 g, 25\%, 2 step).

${ }^{1} \mathrm{H}$ NMR (400 MHz, DMSO-d $)$ ): $\delta 9.20$ (s, 1H), 7.48 (d, $J$ $=8.4 \mathrm{~Hz}, 2 \mathrm{H}), 6.88(\mathrm{~d}, J=8.4 \mathrm{~Hz}, 2 \mathrm{H}), 3.79(\mathrm{~s}, 3 \mathrm{H}), 3.31$ $(\mathrm{q}, J=6.0 \mathrm{~Hz}, 1 \mathrm{H}), 2.58-2.39(\mathrm{~m}, 3 \mathrm{H}), 2.11-1.94(\mathrm{~m}, 3 \mathrm{H})$, 1.87-1.71 (m, 2H).

2-Methoxy-7,8,9,10-tetrahydrophenanthridin-6(5H)-one (18). Ketamide 17 ( $2.0 \mathrm{~g}, 8.09 \mathrm{mmol})$ was suspended in 50 $\mathrm{mL}$ of $70 \% \mathrm{H}_{2} \mathrm{SO}_{4}$ and the resulting mixture was stirred at room temperature for $14 \mathrm{hr}$. The reaction mixture was poured into ice water and stirred for $30 \mathrm{~min}$. The precipitate was filtered, washed with water, and dried in vacuo to afford the title compound $\mathbf{1 8}$ as a brown solid (1.7 g, 91\%).

${ }^{1} \mathrm{H}$ NMR (400 MHz, DMSO-d $): \delta 11.52(\mathrm{~s}, 1 \mathrm{H}), 7.22(\mathrm{~d}$, $J=8.0 \mathrm{~Hz}, 2 \mathrm{H}), 7.10$ (s, 1H), 7.09 (d, $J=8.0 \mathrm{~Hz}, 2 \mathrm{H}), 3.79$ $(\mathrm{s}, 3 \mathrm{H}), 2.80(\mathrm{~s}, 2 \mathrm{H}), 2.46(\mathrm{~d}, J=6.8 \mathrm{~Hz}, 2 \mathrm{H}), 1.78(\mathrm{~d}, J=$ $5.6 \mathrm{~Hz}, 2 \mathrm{H}), 1.71(\mathrm{~d}, J=5.6 \mathrm{~Hz}, 2 \mathrm{H})$.

2-Hydroxy-7,8,9,10-tetrahydrophenanthridin-6(5H)-one (19). To a stirred solution of 2-methoxy-7,8,9,10-tetrahydrophenanthridin-6(5H)-one $18(1.0 \mathrm{~g}, 4.36 \mathrm{mmol})$ in dichloromethane $(1.5 \mathrm{~mL})$ was added dropwise $1 \mathrm{M} \mathrm{BBr}_{3}$ in dichloromethane $(20 \mathrm{~mL})$. The resulting mixture was stirred at room temperature for $2 \mathrm{hr}$. After completion, the mixture was poured into ice water and stirred for $0.5 \mathrm{hr}$. The precipitate was filtered, washed with water, and dried in vacuo to afford the title compound $\mathbf{1 9}$ as a yellow solid $(800 \mathrm{mg}$, $85 \%)$.

${ }^{1} \mathrm{H}$ NMR (400 MHz, DMSO- $\left.d_{6}\right): \delta 11.42(\mathrm{~s}, 1 \mathrm{H}), 9.33(\mathrm{br}$, $1 \mathrm{H}), 7.13(\mathrm{~d}, J=8.0 \mathrm{~Hz}, 1 \mathrm{H}), 6.97(\mathrm{~s}, 1 \mathrm{H}), 6.92(\mathrm{~d}, J=8.0$ $\mathrm{Hz}, 1 \mathrm{H}), 2.71(\mathrm{~s}, 2 \mathrm{H}), 2.44(\mathrm{~d}, J=5.6 \mathrm{~Hz}, 2 \mathrm{H}), 1.76$ (d, $J=$ $4.8 \mathrm{~Hz}, 2 \mathrm{H}), 1.69$ (d, $J=4.8 \mathrm{~Hz}, 2 \mathrm{H})$.

tert-Butyl 4-(6-oxo-5,6,7,8,9,10-hexahydrophenanthridin-2-yloxy)piperidine-1-carboxylate (21). To a stirred solution of the alcohol $19(100 \mathrm{mg}, 0.46 \mathrm{mmol})$ in isopropyl alcohol (3 mL) was added $\mathrm{KOH}(117 \mathrm{mg}, 2.09 \mathrm{mmol})$, and the mixture was refluxed for $30 \mathrm{~min}$. Then, tert-butyl 4bromopiperidine-1-carboxylate $20(430 \mathrm{mg}, 1.63 \mathrm{mmol})$ in isopropyl alcohol $(3 \mathrm{~mL})$ was added dropwise and the stirring was continued at reflux temperature for 2 day. The mixture was cooled to room temperature and evaporated under reduced pressure. The residue was then purified by flash column chromatography (hexane:ethyl acetate $=1: 1$ ) to afford the title compound $\mathbf{2 1}$ as a yellow solid (48 $\mathrm{mg}$, $26 \%$ ).

${ }^{1} \mathrm{H}$ NMR (400 MHz, DMSO- $\left.d_{6}\right): \delta$ 10.61-10.38 (br, 1H), $7.20(\mathrm{~d}, J=4.2 \mathrm{~Hz}, 1 \mathrm{H}), 7.15(\mathrm{~d}, J=4.4 \mathrm{~Hz}, 1 \mathrm{H}), 4.46(\mathrm{~m}$, $1 \mathrm{H}), 3.75-3.69(\mathrm{~m}, 2 \mathrm{H}), 3.37-3.31(\mathrm{~m}, 2 \mathrm{H}), 2.83-2.80(\mathrm{~m}$, $2 \mathrm{H}), 2.70-2.67(\mathrm{~m}, 2 \mathrm{H}), 1.95-1.72(\mathrm{~m}, 8 \mathrm{H}), 1.47(\mathrm{~s}, 9 \mathrm{H})$.

2-(Piperidin-4-yloxy)-7,8,9,10-tetrahydrophenanthridin6(5H)-one Hydrochloride (22). To a stirred solution of 
Boc-(6-oxo-5,6,7,8,9,10-hexahydrophenanthridin-2-yloxy)piperidine 21 (48 $\mathrm{mg}, 0.12 \mathrm{mmol}$ ) in 1,4-dioxane $(3 \mathrm{~mL})$ was added $3.7 \mathrm{M} \mathrm{HCl}$ in 1,4 -dioxane $(1 \mathrm{~mL})$ at $0{ }^{\circ} \mathrm{C}$, and the mixture was stirred for $12 \mathrm{hr}$ at room temperature. The reaction mixture was concentrated in vacuo to give the title compound 22 as a yellow solid (37 $\mathrm{mg}, 92 \%)$.

${ }^{1} \mathrm{H}$ NMR (400 MHz, DMSO- $\left.d_{6}\right): \delta 11.56(\mathrm{~s}, 1 \mathrm{H}), 9.16(\mathrm{br}$, $2 \mathrm{H})$, 7.25-7.15 (m, 3H), 4.70-4.67 (m, 1H), 3.27-3.18 (m, $2 \mathrm{H}), 3.07-3.02(\mathrm{~m}, 2 \mathrm{H}), 2.82-2.77(\mathrm{~m}, 2 \mathrm{H}), 2.46-2.41(\mathrm{~m}$, 2H), 2.12-2.07 (m, 2H), 1.88-1.69 (m, 6H).

General Procedure for the Synthesis of 2-(1-substitutedpiperidin-4-yloxy)-7,8,9,10-tetrahydrophenanthridin6(5H)-one Derivatives (23a-c). To a stirred solution of 2(piperidin-4-yloxy)-7,8,9,10-tetrahydrophenanthridin-6(5H)one hydrochloride 22 (50 mg, $0.15 \mathrm{mmol}$ ) in $\mathrm{MeOH} / \mathrm{di}-$ chloromethane $(3 \mathrm{~mL} / 3 \mathrm{~mL})$ were added sequentially an appropriate aldehyde ( 2 equiv.), $\mathrm{AcOH}(10 \mu \mathrm{L}, 0.18 \mathrm{mmol})$, and $\mathrm{NaB}(\mathrm{OAc})_{3} \mathrm{H}(79 \mathrm{mg}, 0.37 \mathrm{mmol})$. The resulting mixture was stirred at room temperature for 3-5 hr and extracted with chloroform. The organic layer was washed with brine, dried over $\mathrm{Na}_{2} \mathrm{SO}_{4}$, and concentrated to dryness. The residue was then purified by flash column chromatography (chloroform:methanol = 10:1) to afford 2-(1-alkylpiperidin-4-yloxy)-7,8,9,10-tetrahydrophenanthridin-6(5H)-one as a free base.

To a stirred solution of 2-(1-alkylpiperidin-4-yloxy)7,8,9,10-tetrahydrophenanthridin-6(5H)-one in 1,4-dioxane (3-5 mL) was added $3.7 \mathrm{M} \mathrm{HCl}$ in 1,4 -dioxane (30 equiv.) at $0{ }^{\circ} \mathrm{C}$. After stirring for $10-12 \mathrm{hr}$ at room temperature, the reaction mixture was concentrated in vacuo to give the title compound 23.

The physical and analytical data of the synthesized title compounds are given, as follows:

2-(1-Methylpiperidin-4-yloxy)-7,8,9,10-tetrahydrophenanthridin-6(5H)-one (23a). White solid; 73\%; ${ }^{1} \mathrm{H}$ NMR (400 MHz, DMSO- $d_{6}$ ): $\delta 11.56$ (s, 1H), 10.81 (br, 1H), 7.26$7.13(\mathrm{~m}, 3 \mathrm{H}), 4.55(\mathrm{~m}, 1 \mathrm{H}), 3.45-3.37(\mathrm{~m}, 2 \mathrm{H}), 3.27-3.04$ (m, 4H), 2.78-2.72 (m, 4H), $2.44(\mathrm{~s}, 3 \mathrm{H}), 2.22-1.87(\mathrm{~m}, 4 \mathrm{H})$, 1.76-1.69 (m, 2H); MS (ESI+) $m / z:[\mathrm{M}+\mathrm{H}]^{+} 313.2$.

2-(1-Ethylpiperidin-4-yloxy)-7,8,9,10-tetrahydrophenanthridin-6(5H)-one (23b). Pink solid; 87\%; ${ }^{1} \mathrm{H}$ NMR (400 MHz, DMSO- $\left.d_{6}\right): \delta 11.53(\mathrm{~s}, 1 \mathrm{H}), 10.62(\mathrm{br}, 1 \mathrm{H}), 7.24-7.11$ $(\mathrm{m}, 3 \mathrm{H}), 4.76-4.54(\mathrm{~m}, 1 \mathrm{H}), 3.49-3.46(\mathrm{~m}, 1 \mathrm{H}), 3.32-3.30$ (m, 1H), 3.12-2.94 (m, 4H), $2.77(\mathrm{~m}, 2 \mathrm{H}), 2.48(\mathrm{~m}, 2 \mathrm{H})$, 2.21-2.09 (m, 2H), 2.02-1.86 (m, 2H), 1.76-1.68 (m, 4H), $1.25(\mathrm{t}, J=7.2 \mathrm{~Hz}, 3 \mathrm{H})$; MS (ESI+) $m / z:[\mathrm{M}+\mathrm{H}]^{+} 327.2$.

2-(1-Propylpiperidin-4-yloxy)-7,8,9,10-tetrahydrophenanthridin-6(5H)-one (23c). White solid; 66\%; ${ }^{1} \mathrm{H}$ NMR (400 MHz, DMSO- $\left.d_{6}\right): \delta 11.56(\mathrm{~s}, 1 \mathrm{H}), 10.82$ (br, $\left.1 \mathrm{H}\right)$, 7.26-7.14 (m, 3H), 4.79-4.56 (m, 1H), 3.52-3.49 (m, 1H), 3.34-3.31 (m, 1H), 3.16-2.93 (m, 4H), $2.79(\mathrm{~m}, 2 \mathrm{H}), 2.45$ $(\mathrm{m}, 2 \mathrm{H}), 2.22-2.16(\mathrm{~m}, 2 \mathrm{H}), 2.03-1.93(\mathrm{~m}, 2 \mathrm{H}), 1.77-1.70$ (m, 6H), $0.91(\mathrm{t}, J=7.2 \mathrm{~Hz}, 3 \mathrm{H})$; MS (ESI+) $m / z:[\mathrm{M}+\mathrm{H}]^{+}$ 341.2.

Docking Study. All the molecular docking studies were performed using the docking software LigandFit module of Discovery Studio 2.5 (Accelrys, San Diego, CA). In this study, the docking of PARP-1 inhibitors into the active site of human PARP-1 was performed. The crystal structure of human PARP-1 (pdb code: 1UK0) obtained from the Protein Data Bank was rened to remove water molecules and to add hydrogen atoms to the whole enzyme at a $\mathrm{pH}$ of 7.0. The ligands were optimized using a forcefield function, CHARMm. Ten poses were docked for each ligand. Among the docked conformations, the over-fitted conformation was eliminated.

PARP-1 Enzyme Inhibitory Activity. The $\mathrm{IC}_{50}$ of PARP inhibitor compounds was determined using Trevigen PARP inhibition kit (Gaithersburg, USA). The assay was performed in 384-well, small volume microplates following a modified previously reported method, ${ }^{20}$ as follows:

The PARP-1 enzyme assay was set up in a volume of 12 $\mu \mathrm{L}$. Wells were coated with diluted histones and incubated at $25{ }^{\circ} \mathrm{C}$ for $2 \mathrm{hr}$. After the plates were washed four times with PBS, all the liquid was removed following each wash by tapping the plate onto paper towels. To block the nonspecific signal, the wells were blocked by adding the Strep-diluent and incubated at $25{ }^{\circ} \mathrm{C}$ for $1 \mathrm{hr}$. The plates were washed four times with PBS, and serial dilutions of compound were added. The diluted PARP-1 enzyme was then added to each well (0.12 unit/well), except for the negative control wells, and combined with a $2 \times$ PARP cocktail. The reaction was allowed to proceed for $30 \mathrm{~min}$ at $25^{\circ} \mathrm{C}$. After washing four times with PBS, streptavidin-linked peroxidase was added to detect the extent of ribosylation, and the plate was incubated at $37{ }^{\circ} \mathrm{C}$ for $30 \mathrm{~min}$. The plates were then washed 4 times with PBS, then the TACS-Sapphire substrate was added and the color allowed to develop for $10 \mathrm{~min}$. Finally, the reaction was stopped by adding $0.2 \mathrm{~N} \mathrm{HCl}$, and the optical densities were read at $450 \mathrm{~nm}$ using a Wallac EnVision ${ }^{\mathrm{TM}}$ plate reader (PerkinElmer Oy, Turku, Finland). All the data points were determined in triplicate and the data were analyzed using SigmaPlot 10 (Systat Software Inc., USA).

Intracellular PARP Inhibitory Activity. This protocol describes a real-time assay to assess an imbalance of DNA single-strand break repair by indirectly measuring PARP activation through the depletion of intracellular NAD $(\mathrm{P}) \mathrm{H}^{21}$ Chinese hamster ovary cells $(\mathrm{CHO}-\mathrm{K} 1)$ were cultured in RPMI media supplemented with $10 \%$ fetal bovine serum (FBS). The cultured CHO-K1 cells were seeded at a density of $2.9 \times 10^{3}$ cells/well in 96 -well plate and cultured at $37^{\circ} \mathrm{C}$ and $5 \% \mathrm{CO}_{2}$ for $16 \mathrm{hr}$. The cells were then treated with various concentrations of the synthesized compounds and incubated at $37^{\circ} \mathrm{C}$ for $2 \mathrm{hr}$. DNA damage was induced using $1.5 \mathrm{mM}$ MMS (methyl methanesulfonate), and the cells were simultaneously treated with a CCK-8 (Cell Count Kit8) solution (DOJINDO, CK01-13) for colorimetric assay. At $4 \mathrm{hr}$ after the treatment with MMS, the amount of NAD(P)H secreted into the culture media was quantified using a Wallac EnVision $^{\mathrm{TM}}$ plate reader at $450 \mathrm{~nm}$. The results obtained according to various concentrations of the compounds are the average values obtained from four wells, and the results were calculated by regression analysis.

Acknowledgments. This study was supported by a grant 
from the Korea Healthcare Technology R\&D Project, Ministry for Health, Welfare \& Family Affairs, Republic of Korea (A100453-1001-0000100).

\section{References}

1. Malanga, M.; Althaus, F. R. Biochemistry and Cell Biology 2005, $83,354$.

2. Amé, J.-C.; Spenlehauer, C.; de Murcia, G. BioEssays 2004, 26, 882.

3. Yu, S. W.; Wang, H.; Poitras, M. F.; Coombs, C.; Bowers, W. J.; Federoff, H. J.; Poirier, G. G.; Dawson, T. M.; Dawson, V. L. Science 2002, 297, 259.

4. Szabo, C.; Dawson, V. L. Trends Pharmacol Sci. 1998, 19, 287.

5. Zaremba, T.; Curtin, N. J. Anticancer Agents Med. Chem. 2007, 7, 515.

6. Calabrese, C. R.; Almassy, R.; Barton, S.; Batey, M. A.; Calvert, A. H.; Canan-Koch, S.; Durkacz, B. W.; Hostomsky, Z.; Kumpf, R. A.; Kyle, S.; Li, J.; Maegley, K.; Newell, D. R.; Notarianni, E.; Stratford, I. J.; Skalitzky, D.; Thomas, H. D.; Wang, L. Z.; Webber, S. E.; Williams, K. J.; Curtin, N. J. J. Natl. Cancer Inst. 2004, 96, 56.

7. Graziani, G.; Battaini, F.; Zhang, J. Pharmacol Res. 2005, 52, 1.

8. Ishida, J.; Yamamoto, H.; Kido, Y.; Kamijo, K.; Murano, K.; Miyake, H.; Ohkubo, M.; Kinoshita, T.; Warizaya, M.; Iwashita, A.; Mihara, K.; Matsuoka, N.; Hattori, K. Bioorg. Med. Chem. 2006, 14, 1378 .

9. Ferraris, D.; Ko, Y. S.; Pahutski, T.; Ficco, R. P.; Serdyuk, L.; Alemu, C.; Bradford, C.; Chiou, T.; Hoover, R.; Huang, S.; Lautar, S.; Liang, S.; Lin, Q.; Lu, M. X.; Mooney, M.; Morgan, L.; Qian, Y.; Tran, S.; Williams, L. R.; Wu, Q. Y.; Zhang, J.; Zou, Y.; Kalish, V. J. Med. Chem. 2003, 46, 3138.
10. Kinoshita, T.; Nakanishi, I.; Warizaya, M.; Iwashita, A.; Kido, Y.; Hattori, K.; Fujii, T. FEBS Lett 2004, 556, 43.

11. Menear, K. A.; Adcock, C.; Boulter, R.; Cockcroft, X. L.; Copsey, L.; Cranston, A.; Dillon, K. J.; Drzewiecki, J.; Garman, S.; Gomez, S.; Javaid, H.; Kerrigan, F.; Knights, C.; Lau, A.; Loh, V. M., Jr.; Matthews, I. T.; Moore, S.; O'Connor, M. J.; Smith, G. C.; Martin, N. M. J. Med. Chem. 2008, 51, 6581.

12. Jagtap, P. G.; Baloglu, E.; Southan, G. J.; Mabley, J. G.; Li, H.; Zhou, J.; van Duzer, J.; Salzman, A. L.; Szabo, C. J. Med. Chem. $\mathbf{2 0 0 5}, 48,5100$.

13. Matsumoto, K.; Kondo, K.; Ota, T.; Kawashima, A.; Kitamura, K.; Ishida, T. Biochim. Biophys. Acta 2006, 1764, 913.

14. Lord, A. M.; Mahon, M. F.; Lloyd, M. D.; Threadgill, M. D. J. Med. Chem. 2009, 52, 868.

15. Penning, T. D.; Zhu, G. D.; Gandhi, V. B.; Gong, J.; Liu, X.; Shi, Y.; Klinghofer, V.; Johnson, E. F.; Donawho, C. K.; Frost, D. J.; Bontcheva-Diaz, V.; Bouska, J. J.; Osterling, D. J.; Olson, A. M.; Marsh, K. C.; Luo, Y.; Giranda, V. L. J. Med. Chem. 2009, 52, 514.

16. Kim, M. H.; Park, C. H.; Joe, B. Y.; Chun, K. W. Patent; KR 102009-0046431.

17. Khuthier, A.-H.; Al-Mallah, K. Y.; Hanna, S. Y.; Abdulla, N.-A. I. J. Org. Chem. 1987, 52, 1710.

18. Stork, G.; Brizzolara, A.; Landesman, H.; Szmuszkovicz, J.; Terrell, R. J. Am. Chem. Soc. 1963, 85, 207.

19. Park, C. H.; Chun, K.; Joe, B. Y.; Park, J. S.; Kim, Y. C.; Choi, J. S.; Ryu, D. K.; Koh, S. H.; Cho, G. W.; Kim, S. H.; Kim, M. H. Bioorganic \& Medicinal Chemistry Letters 2010, 20, 2250.

20. Lee, S.; Koo, H. N.; Lee, B. H. Methods Find Exp. Clin. Pharmacol $\mathbf{2 0 0 5}, 27,617$.

21. Nakamura, J.; Asakura, S.; Hester, S. D.; de Murcia, G.; Caldecott, K. W.; Swenberg, J. A. Nucleic. Acids Res. 2003, 31, e104. 